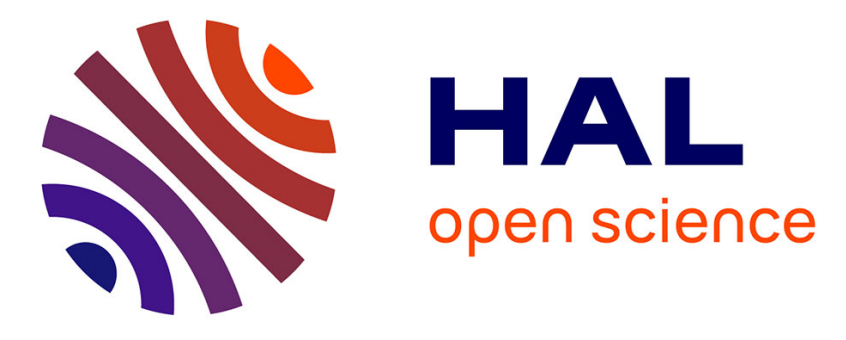

\title{
Toward a Play Management System for Play-Based Learning
}

Eric Sanchez, Claudine Piau-Toffolon, Lahcen Oubahssi, Audrey Serna, Iza Marfisi-Schottman, Guillaume Loup, Sébastien George

\section{- To cite this version:}

Eric Sanchez, Claudine Piau-Toffolon, Lahcen Oubahssi, Audrey Serna, Iza Marfisi-Schottman, et al.. Toward a Play Management System for Play-Based Learning. European Conference on Technology Enhanced Learning,, Sep 2016, Lyon, France. pp.484 - 489, 10.1007/978-3-319-45153-4_47 . hal01383214

\section{HAL Id: hal-01383214 https://hal.science/hal-01383214}

Submitted on 19 Oct 2016

HAL is a multi-disciplinary open access archive for the deposit and dissemination of scientific research documents, whether they are published or not. The documents may come from teaching and research institutions in France or abroad, or from public or private research centers.
L'archive ouverte pluridisciplinaire HAL, est destinée au dépôt et à la diffusion de documents scientifiques de niveau recherche, publiés ou non, émanant des établissements d'enseignement et de recherche français ou étrangers, des laboratoires publics ou privés. 


\title{
Toward a Play Management System for Play-Based Learning
}

\author{
Eric Sanchez ${ }^{1}$, Claudine Piau-Toffolon ${ }^{2}$, Lahcen Oubahssi ${ }^{2}$, Audrey Serna ${ }^{3}$, Iza \\ Marfisi-Schottman ${ }^{2}$, Guillaume Loup ${ }^{2}$, and Sébastien George ${ }^{2}$ \\ ${ }^{1}$ Ecole Normale Supérieure de Lyon, France \& University of Fribourg, Switzerland \\ eric.sanchez@unifr.ch \\ ${ }^{2}$ Université Bretagne Loire, Université du Maine, LIUM, 72085 Le Mans, France \\ \{claudine.piau-toffolon, lahcen.oubahssi, iza.marfisi, \\ guillaume.loup, sebastien.georgeduniv-lemans.fr\} \\ ${ }^{3}$ INSA de Lyon, LIRIS, UMR5205, F-69622, France \\ audrey.serna@insa-lyon.fr
}

\begin{abstract}
This position paper is dedicated to describing a preliminary model of an integrated system, called Play Management System (PMS). PMS is designed to support both players and teachers to deliver, use, manage and track play situations. This PMS model results from a design-based research methodology. Our approach focuses on (1) the learners and the situation that emerges when they play the game, rather than the system dedicated to play and (2) the teachers who want to manage a game-based learning situation. Thus, we argue for a shift from a game-based to a play-based perspective.
\end{abstract}

Keywords: Game-Based Learning, Play Management System, Classroom Orchestration, Design-Based Research, Teachers' Requirement Analysis

\section{Introduction}

Within a context marked by the development of alternative pedagogies, this position paper aims to describe a model of an integrated system, called Play Management System (PMS), dedicated to support players and teachers to deliver, use, manage and track play situations. The purpose of this article is to propose an innovative approach for implementing a play-based learning approach by (1) focusing on the learners and taking into consideration the situation that emerges when they play rather than the artifact dedicated to play (play vs game) and (2) focusing on the teachers who want to implement and manage a play-based learning situation in their classroom (play management $v s$ game design). Thus, we address the issue of teachers' requirements for the orchestration of a play situation within an educational context. In the first section of this paper, we advocate for a player-centered approach for game-based learning. The second section presents a game developed during the project and the design-based research methodology adopted for designing this game. The third section describes 
the model of a Play Management System, based on the results that emerged implementing and testing a game in real school contexts

\section{Switching from Game to Play}

Digital Epistemic Games (referend to as JENs ${ }^{1}$ in this paper) are playful and authentic learning situations that lead the learners to solve complex, interdisciplinary and nondeterminist problems. JENs allow students to develop their own ways of thinking and acting by designing and trying out their own solutions [2,3]. JENs also rely on mixed reality technologies [5] to create contextual and situated activities and to support knowledge co-construction among learners. "Learning situation" are key words of this definition and Henriot emphasized the importance of distinguishing the game, as an artifact, and play, its usage [6]. For Henriot, play emerges from the interactions between a player and a game. In other words, play depends on the lusory attitude [7] of the players, i.e. their willingness to take on the rules of the game and to participate. Usually, studies on game-based learning are focused on the characteristics of a given game. We consider that it is the learning situation in which the game is used that is paramount, and that a shift from a game-based to a play-based perspective is needed.

Implementing a game-based pedagogy implies that the teachers have to manage the classroom orchestration [8]. Their role entails the introduction of the game to the students. A teacher may also act as a game master and be involved in the assignment of rewards, if it is not automatic. Following a gamification trend, for some Learning Management Systems such as Moodle ${ }^{2}$, badge functionalities enable students to represent their achievements and skills. Such an approach has been implemented for the game Classcraft ${ }^{3}$, designed for classroom management. The success of the game, in terms of its adoption by teachers, demonstrates its relevance [9]. Another teachers' roles relates to the animation of debriefing sessions, dedicated to foster reflection and metacognition after the game, or in-between game sessions [10]. Regarding the importance and the complexity of the teachers' role for game-based learning, it becomes apparent that they need to be taken into account when designing a technical solution to implement their game and that such a solution should include support for dynamic classroom orchestration.

\section{$3 \quad$ Play Management System Requirement Analysis}

The methodology of this research work is based on the collaboration of practitioners (teachers) and researchers. Thereafter, the objectives are both pragmatic (producing innovative digital applications adapted to the teachers' expectations) and theoretical (developing new models for instruction and learning). As a result, the methodology applied is influenced by the Design-Based Research (DBR) approach [11]. This de-

\footnotetext{
${ }^{1}$ JEN stands for Jeu Epistémique Numérique in French

2 https://moodle.com/, visited on March 2016

${ }^{3}$ http://www.classcraft.com/fr/, visited on March 2016
} 
sign process is combined with the analysis of these educational practices, carried out collaboratively by researchers and practitioners. In the field of Technology Enhanced Learning, DBR has close relationships with software design methodologies that aim to integrate end-users in the early stages of the design process, such as Agile or usercentered methodologies [13] and participatory design [12] from the Human Computer Interaction field. Considering our needs for play orchestration of JENs, we therefore choose to apply DBR for the analysis of the teachers' requirement. In order to provide an example of the JENs designed with this method, let us present Insectophagia, one of the three games we designed with teachers.

Insectophagia is a game that convers the principles of sustainable development. This game was designed for five classes (86 students) from 15 to 17 years old. The global objective, for each team (composed of 3 or 4 learners) is to create a start-up company, specialized in insect-based food production. First, the team needs to choose the type of insect they want to farm, based on ecological and dietary properties. Then, they have to find a proper location to build their factory and make the right investments in terms of sustainable energy sources. Finally, they need to come up with an innovative and appealing product for customers. The players use digital technologies and real-world settings depending on the performed mission. The game lasts approximatively 7 weeks (approx. 18 hours) depending on the school. Rewards and points depend on how the players manage to deal with environmental, social and economic issues. The teacher is responsible for introducing the different missions, rewarding the students, time keeping and also for chairing the debriefing session. We also designed two other very different JENs: Rearth, a science-fiction game dedicated to science and programming and Generalisima, an exploration game, used by a company to train their employees.

Six design sessions, involving researchers and teachers, were dedicated to define the learning objectives, the game universe and the gameplay of the JENs. Several students also participated and provided ideas. After the design phase, we developed prototypes that were partial paper-based and partial digital. The main structure of the game was paper-based (e.g. paper cards, tokens representing points, game booklet) while punctual activities were completed on computers (e.g. documentary research, smartphone game for exploring the potential locations for the farm). The prototype was experimented in naturalistic conditions by the teachers involved in the design phase. After the experimentation, two sessions were organized to discuss the lessons learned from the experimentation of the JENs. From the teachers' point of view, the game was valuable for students since they were immerged in a complex situation for which they had to collaborate and use various resources. However, the pedagogical situation emerging from this game was not easy to manage in real-time in the classroom. The teachers expressed the need for a tool dedicated to manage class orchestration (assigning specific goals to players, organizing teams) and play management (rewarding successful players with points and badges). These fruitful discussions helped us to define a preliminary generic model of PMS for JENs. 


\section{Towards a Play Management System}

The first user studies described previously support the need for a generic system, dedicated to play management. We describe the global architecture of the system and the functionalities that we identified.

\subsection{A System Dedicated to Play Management}

We called this platform Play Management System (PMS) in reference to Learning Management Systems (LMS). Indeed, there are several analogies between PMS and LMS: the shift from game to play is an analogy of the shift from teaching to learning, in line with a learner-centered approach for education; the shift from a resourcecentered to an activity-centered approach, in line with the Educational Modelling Language community approach [14]; and finally, management system refers to the complexity of the game master's roles: designing and implementing the learning/gaming situation, real-time tutoring and assessing/rewarding, and debriefing.

Figure 1 summarizes the main ideas behind the PMS as discussed during debriefing session. A PMS is an integrated system that supports players and teachers to carry out play-based learning. This system, separated from the game itself (JEN units), supports the different dimensions of an educational play situation (learning context, game documents, game characteristics, social interactions, and technological aspects). As a result, the PMS may be used to plan, implement, and assess specific learning processes based on play activities.

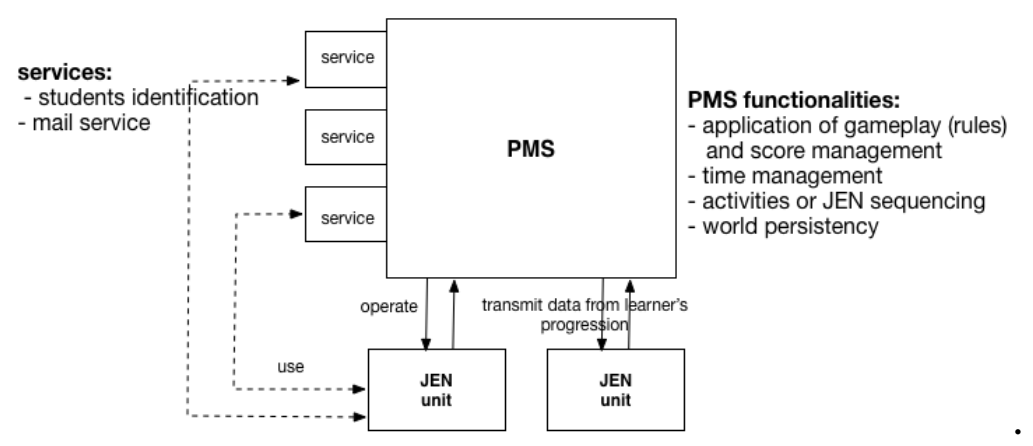

Fig. 1. A global scheme of the PMS emerging from debriefing sessions

Within a JEN, both individual play and collaborative play must be encouraged. Therefore, a PMS must offer the means for developing individual and collaborative activities that foster production, communication and coordination [15].

There is also a need, for the teacher to track play activities in order to get information about players' achievements. Indeed, the teacher's expressed the need for PMS to take into consideration data collection (traces) for the asynchronous analysis of players' interactions. As a result, learning analytics [16] services might be offered. 
Since traditional Learning Management Systems (LMS) have been developed to manage learning situations such as online or hybrid courses, they do not offer all the functionalities and dedicated interactions needed to manage play situation and they are not well suited to the specific needs of JENs. We therefore propose a new architecture.

\subsection{Toward a Play Management System Architecture}

The ideas expressed by the teachers and researchers during the debriefing sessions, show that the PMS architecture should be composed of 4 modules with a set of functionalities. (1) The Administrator Module offers the functionalities to customize the PMS, manage user accounts, the resources needed to play (documents for students) and the technical aspects of the game. (2) The Player/Learner Module offers all the functionalities for each individual player to perform the missions of the game and also to customize her/his personal data and avatar. (3) The Game Master Module is dedicated to dynamic orchestration. Teachers have the possibility to define (or redefine) specific goals, to organize teams of learners and to reward the players with points and badges. The PMS also offers different tools to support interactions between players and between players and the teacher (as a game master). (4) The Service Module provides teachers and learners with generic functionalities that can be used at any time during the JEN. These functionalities offer numerous ways of enhancing the play experience with specific reward tools (leader board, points, badges...), supporting collaborative work (collaborative production tools, task management tools...) and communication (chat, forum, mail...), and also tracking actions performed by the players (learning analytics).

\section{Conclusion}

The goal of this study was to propose an innovative approach for implementing playbased learning into secondary education. Since we decided to implement a playercentered approach for game-based learning and to offer support for dynamic classroom orchestration, a new perspective emerged. A PMS is an integrated system that supports players and teachers to deliver, use, manage, and track play situations dedicated to educational objectives. This system may be used to plan, implement, and assess Digital Epistemic Games. The PMS model proposed in this paper is composed of four modules: Administration Module, Player/Learner Module, Game-Master Module and Service Module.

The contributive, collaborative and iterative methodology based on experimentation in real school settings enabled linking pragmatic issues (implementing a game in a classroom) and theoretical issues (designing a model of a system adapted to play management). The main results consist of the identification of the functionalities needed for play orchestration (i.e. teachers' requirements). New experimentations are now conducted. The preliminary results underline that the persistence of the game has been recognized to be important. Thus, the prototype now offers the players the opportunity to consult their logbook, refreshed in real time. It is expected that PMS, by 
taking on the issue of persistence, will sustain the players' motivation and enhance decision making. In sum, the lessons learned from the ongoing experimentations, lead us to better take into consideration players' requirements.

Acknowledgments. The JEN.lab project is a multi-disciplinary project funded by the French Research Agency (ANR-13-APPR-0001). The authors want to thank the students and teachers for their full support and key contributions.

\section{References}

1. Sanchez, E.: Learning, Serious Games, and Gamification. Inmedia. (2014)

2. Shaffer, D.: Epistemic Frames for Epistemic Games. Computers and Education. 3. vol. 46. pp 223-234 (2006)

3. Ohlsson, S.: Learning to Do and Learning to Understand: A Lesson and a Challenge for Cognitive Modeling. In P. Reiman \& H. Spade (Eds.). Learning in Humans and Machines: Towards an interdisciplinary learning science. pp. 37-62. Elsevier Science. Oxford, UK (1995)

4. Baker, M.: Argumentation and Constructive Interaction. In P. Coirier \& J. Andriessen (Eds.), Foundations of Argumentative Text Processing. vol. 5. pp. 179-202. University of Amsterdam Press. Amsterdam, NL (1999)

5. Milgram, P., \& Kishino, F. A Taxonomy of Mixed Reality Visual Displays. IEICE (Institute of Electronics, Information and Communication Engineers) Transactions on Information and Systems, Special Issue on Networked Reality. 77. pp. 1321-1329 (1994)

6. Henriot, J.: Le jeu. Presses Universitaires de France, Paris (1969)

7. Suits, B.: Grasshopper: Games, Life and Utopia. David R. Godine. Boston (1990)

8. Dillenbourg, P.: Design for Classroom Orchestration. Journal of Computers in Education. vol. 69 pp 485-492 (2013)

9. Sanchez, E., Young, S., Jouneau-Sion, C.: Classcraft: from Gamification to Ludicization of Classroom Management. Education and Information Technologies, 5. vol. 20. pp 1-17 (2016)

10. Garris, R., Ahlers, R., Driskell, J. E.: Games, Motivation, and Learning: A Research and Practice Model. Simulation \& Gaming. 4. vol. 33. pp. 441-467 (2002)

11. Design-Based Research Collective. Design-based research: An Emerging Paradigm for Educational Inquiry. Educational Researcher. 1. vol. 32. pp. 5-8 (2003)

12. Schuler, D., Namioka, A. (Eds.): Participatory Design: Principles and Practices. P. Lawrence Erlbaum Associates. Hillsdale (1993)

13. Highsmith, J.: Agile Software Development Ecosystems. Addison-Wesley Professional. Boston, MA (2002)

14. Giesbers, B., van Bruggen, J., Hermans, H., Joosten-ten Brinke, D., Burgers, J., Koper, R., Latour, I.: Towards a Methodology for Educational Modelling: a Case in Educational Assessment. Educational Technology \& Society. 1. vol. 10. pp 237-247 (2007)

15. Ellis C.A., Gibbs S.J., Rein G.L.: Groupware: some Issues and Experiences, Communication of ACM. 1. vol. 34. pp. 39-58 (1991)

16. Long, P., \& Siemens, G.: Penetrating the Fog: Analytics in Learning and Education. Educause Review Online. 5. vol. 46. pp. 31-40 (2011) 